\title{
Loss of Quinone Reductase 2 Function Selectively Facilitates Learning Behaviors
}

\author{
Charles-Etienne Benoit, ${ }^{1,2}$ Stephane Bastianetto, ${ }^{1}$ Jonathan Brouillette, ${ }^{1}$ YiuChung Tse, ${ }^{1}$ Jean A. Boutin, ${ }^{3}$ \\ Philippe Delagrange, ${ }^{3}$ TakPan Wong, ${ }^{1}$ Philippe Sarret, ${ }^{2}$ and Rémi Quirion ${ }^{1}$ \\ ${ }^{1}$ Douglas Mental Health University Institute, Department of Psychiatry, McGill University, Verdun, Québec, Canada, H4H 1R3, ${ }^{2}$ Département de \\ Physiologie et Biophysique, Faculté de Médecine et des Sciences de la Santé, Université de Sherbrooke, Sherbrooke, Québec, Canada, J1H 5N4, and \\ ${ }^{3}$ Pharmacologie Moléculaire et Cellulaire, Institut de Recherche Servier, 78290 Croissy-sur-Seine, France
}

High levels of reactive oxygen species (ROS) are associated with deficits in learning and memory with age as well as in Alzheimer's disease. Using DNA microarray, we demonstrated the overexpression of quinone reductase $2(\mathrm{QR} 2)$ in the hippocampus in two models of learning deficits, namely the aged memory impaired rats and the scopolamine-induced amnesia model. QR2 is a cytosolic flavoprotein that catalyzes the reduction of its substrate and enhances the production of damaging activated quinone and ROS. QR2-like immunostaining is enriched in cerebral structures associated with learning behaviors, such as the hippocampal formation and the temporofrontal cortex of rat, mouse, and human brains. In cultured rat embryonic hippocampal neurons, selective inhibitors of QR2, namely S26695 and S29434, protected against menadione-induced cell death by reversing its proapoptotic action. $S 26695(8 \mathrm{mg} / \mathrm{kg})$ also significantly inhibited scopolamine-induced amnesia. Interestingly, adult QR2 knock-out mice demonstrated enhanced learning abilities in various tasks, including Morris water maze, object recognition, and rotarod performance test. Other behaviors related to anxiety (elevated plus maze), depression (forced swim), and schizophrenia (prepulse inhibition) were not affected in QR2-deficient mice. Together, these data suggest a role for QR2 in cognitive behaviors with QR2 inhibitors possibly representing a novel therapeutic strategy toward the treatment of learning deficits especially observed in the aged brain.

\section{Introduction}

The aging brain undergoes multiple complex molecular modifications, which can result in learning impairments ranging from minor senility to neurodegenerative disorders (Mattson and Magnus, 2006). To ensure the maintenance of high cognitive functions in aging, the induction of a cascade of genes and their translated products is required (Igaz et al., 2002). Interestingly, significant individual differences are observed in learning capacities with age in both humans and animals (Mattson and Magnus, 2006). Over the past few years, we and others have used aged memory impaired (AI) and memory unimpaired (AU) rats as a model to better characterize molecular and functional differences between highly successful and less successful agers (Gage et al., 1989; Frick et al., 1995; Rowe et al., 1998; Stemmelin et al., 2000; Brouillette and Quirion, 2008). Recently, we reported that various groups of genes are differentially expressed in AI and AU rats possibly explaining some of the observed deficits in learning abil-

\footnotetext{
Received June 2, 2010; revised July 22, 2010; accepted Aug. 2, 2010.

This work was supported by grants from the Canadian Institutes of Health Research (CIHR) (R.Q.). J.B. was holding a studentship award from the Fonds de la Recherche en Santé du Québec (FRSQ) during his thesis. P.S. is a CIHR new investigator and member of the FRSQ funded Centre de Recherche Clinique Étienne Lebel. T.P.W. is a Junior Research Scholar of FRSQ. We thank Danielle Cécyre from the Quebec Brain Bank for assistance, to Mira Thakur for editing and proofreading the manuscript, and Jean-Guy Chabot for microscopy expertise. The Quebec Brain Bank is supported in part by FRSQ and by the Douglas Institute Foundation.

Correspondence should be addressed to Dr. Rémi Quirion, Douglas Mental Health University Institute, McGill University, 6875 LaSalle Boulevard, Montréal, QC, Canada, H4H 1R3. E-mail address: remi.quirion@douglas. mcgill.ca.

DOI:10.1523/JNEUROSCI.2808-10.2010

Copyright $\odot 2010$ the authors $\quad 0270-6474 / 10 / 3012690-11 \$ 15.00 / 0$
}

ities. Among those various genes, one in particular has attracted our attention, because it was found to be overexpressed not only in the AI-AU model but also in a well-established pharmacological model of amnesia, the scopolamine-treated rat (Brouillette et al., 2007). This gene encodes for quinone reductase 2 (QR2), a cytosolic flavoprotein that catalyzes the reduction of its substrate and enhances the production of damaging activated quinone and reactive oxygen species (ROS) (Vella et al., 2005; Gong et al., 2008). Higher levels of ROS in aging were shown to be associated with cognitive deficits (Serrano and Klann, 2004).

Very limited information is currently available on the expression, discrete distribution, and possible role of QR2 in the mammalian brain (Vella et al., 2005). It was shown recently that the human QR2 promoter contains a binding site for the transcription factor Sp3 that represses QR2 gene transcription (Wang and Jaiswal, 2004). Moreover, a polymorphism in that region of the promoter has been suggested as a relatively weak susceptibility factor in the etiology of schizophrenia (Harada et al., 2003), Parkinson's disease (Harada et al., 2001; Wang et al., 2008), and other related mental disorders (Okubo et al., 2003; Ohgake et al., 2005). Accordingly, the major objective of the present study was first to demonstrate its expression and distribution in discrete mammalian brain. Having established its particular enrichment in the hippocampus and cortex, two key structures involved in cognitive behaviors, we next investigated the possible role of QR2 in learning using various molecular and pharmacological approaches. Our results suggest a role for QR2 in neuroprotective and learning-related behaviors, its activation leading to decreased 
capacities. The use of QR2 inhibitors should thus be considered as a novel therapeutic strategy in the treatment of diseases associated with loss of cognitive abilities.

\section{Materials and Methods}

Animals. Male Long-Evans rats were purchased from Charles River. Pregnant dams were obtained from the same supplier. Adult male QR2 homozygous (-/-) mice were obtained from Servier Pharmaceutical on a private order to Charles River and maintained in the BL/6 backgrounds (Mailliet et al., 2005). Wild-type (WT) $(+/+)$ male littermates were used as controls in all experiments. All tested animals were 3-4 months old. All animals were kept on a $12 \mathrm{~h}$ light/dark cycle with ad libitum access to food and water. Animal care and handling procedures were approved by the McGill University Animal Care Committee and by the Canadian Council on Animal Care.

Drugs. (-)-Scopolamine hydrobromide (Sigma) was dissolved in physiological saline and administered $(2 \mathrm{mg} / \mathrm{kg}$, i.p.) daily for 5 consecutive days, $20 \mathrm{~min}$ before Morris water maze (MWM) training. Control animals received an equal volume of physiological saline. The QR2 inhibitors S29434 and S26695 were developed by Servier Pharmaceutical. S26695 was dissolved for the scopolamine experiment in DMSO and then kept from the stock solution to a maximum of $10 \%$ DMSO with physiological saline. S29434 and S26695 were dissolved in DMSO for hippocampal cell culture experiments.

Microarray analysis. Tissues used for microarray analysis were taken from the rostral end of the dorsal hippocampus up to the tip of the ventral hippocampus of 24- to 25-month-old AI and AU rats as well as from 4-month-old scopolamine-treated rats. These coordinates are known to include all regions of the dorsal hippocampus proper (dentate gyrus, CA1, and CA3). The dorsal hippocampus was dissected immediately after decapitation and stored at $-80^{\circ} \mathrm{C}$ in RNAlater stabilization reagent until use. The frozen tissues were ground and used for the different molecular analyses. We used total dorsal hippocampal tissue instead of a more restricted brain region for microarray analysis. This approach provides information regarding widespread gene expression modification in the neurotransmitter systems involved in learning within this structure. Total RNA was isolated using RNeasy Lipid Tissue kit with RNase-Free DNase Set (Qiagen) to ensure maximal removal of DNA during RNA purification. The RNA quality and concentration were assessed with Agilent Technologies 2100 Bioanalyser. Quadruplicates of Affymetrix GeneChip Rat Genome 2302.0 array were used in each group of animals. The microarray primary data were deposited, using MIAMExpress, in the ArrayExpress database with the accession number E-MEXP-920. The raw intensity reading of each individual target on the Affymetrix microarray was processed and normalized by using the $\log _{2}$ scale robust multi-array averaging (RMA) method. Because the RMA method gives less pronounced fold change (FC) magnitudes compared with the Affymetrix Microrray Suite 5.0 analysis default program, a minimal FC of 1.5 is suggested as exclusion criteria to select genes and avoid false negatives (Irizarry et al., 2003). Minus versus average plots were performed to control interanimal variation within and between groups.

Quantitative reverse transcription-PCR analysis. Two-step quantitative real-time reverse transcription (RT)-PCR was performed to confirm microarray results according to Applied Biosystems guidelines. Reverse transcription of total RNA was performed with TaqMan Reagents (Qiagen). The cDNA generated was directly quantified by measuring the increase in fluorescence with the SYBR Green PCR Core Reagents (Qiagen) during the PCR using the GeneAmp 5700 Sequence Detection System ( 40 cycles; Applied Biosystems). The endogenous control $\beta$-actin was used to normalize quantification of the mRNA target, and nonspecific amplifications were verified by a dissociation curve. All reactions were performed in triplicate.

Generation of a chicken polyclonal anti-hQR2 antibody. Polyclonal antibody directed against hQR2 protein was custom made by Kernov. Briefly, two hens were immunized with purified 6His-hQR2 (expressed in Sf9 insect cells), five times at $200 \mu \mathrm{g}$ : days $0,14,28,49$, and 70, using complete Freud's adjuvant. The eggs were collected daily and blood samples were collected at days 35 and 77. IgG was purified from egg yolk (preimmune eggs and hyperimmune eggs) by affinity chromatography against immobilized hQR2. Hen sera of immunized eggs were tested for their QR2-specific antibody content by anti-hQR2 ELISA. Sera eggs were then pooled for each hen to obtain final polyclonal anti-hQR2 solution.

Immunohistochemical study in rodent brain. Rodents (3- to 4-monthold mice and rats) were anesthetized with a mixture of ketamine (50 mg/kg; McGill Animal Center), xylazine (5 mg/kg; McGill Animal Center), and acepromazine maleate ( $1 \mathrm{mg} / \mathrm{kg}$; McGill Animal Center), given intramuscularly. Animals were then perfused intracardially with PBS, pH 7.4, followed by $4 \%$ paraformaldehyde in $0.1 \mathrm{~m}$ phosphate buffer, $\mathrm{pH} 7.4$, for 15-20 min. Brains were removed and transferred to $30 \%$ sucrose in phosphate buffer at $4^{\circ} \mathrm{C}$ and then frozen in 2-methylbutane. Sections at $35 \mu \mathrm{m}$ were cut on a sliding microtome and collected in cold phosphate buffer. Sections were then immunohistochemically processed for the presence of QR2 using the avidin-biotin complex procedure and Vectastain reagents (Vector Laboratories). Sections were first incubated in chicken anti-QR2 antibody $(1: 1000)$ overnight at $4^{\circ} \mathrm{C}$. After a thorough rinse in TBS, sections were incubated with the biotinylated goat antichicken secondary antibody (1:200; Vector Laboratories) for $60 \mathrm{~min}$ at room temperature. QR2 staining was detected using the avidinbiotinylated enzyme complex and diaminobenzidine $/ \mathrm{H}_{2} \mathrm{O}_{2}$ reaction according to the instructions of the manufacturer. Sections were then mounted, dried, and coverslipped for microscopic investigation. The same procedure was used for control experiments except that sections were processed either with antibodies preabsorbed overnight with an excess of immunizing peptide or in the absence of primary antibody.

Immunohistochemistry in human brain tissues. Postmortem human brain tissues were obtained from the Douglas Institute Brain Bank, which is part of the Quebec Brain Bank. For immunohistochemistry and image analysis, fixed paraffin-embedded tissues from the hippocampus, amygdala, and frontal cortex were used. The control subjects had no clinical history of psychiatric or neurological disorders nor did their brains exhibit any neuropathological characteristics of dementia. These subjects had died suddenly (triplicate of 41, 44, and 76 years old); after arrival at the Quebec Brain Bank, each brain was hemisected and one hemisphere was fixed in $4 \%$ buffered Formalin, whereas the other hemisphere was frozen at $-80^{\circ} \mathrm{C}$. Fixed brain tissues were processed by routine paraffin embedding, sectioned into 8- $\mu \mathrm{m}$-thick sections, and used for QR2 immunostaining. Immunohistochemical detection was performed on Formalin-fixed paraffin-embedded tissue. Sections were deparaffinized and rinsed in Tris- $\mathrm{NaCl}$ buffer (TBS) $(0.05 \mathrm{M}$ Tris and $0.15 \mathrm{M} \mathrm{NaCl}, \mathrm{pH}$ 7.6) and treated with $1 \%$ hydrogen peroxide $(30 \mathrm{~min})$ to quench endogenous peroxidase activity. For antigen retrieval, sections were boiled in $0.05 \mathrm{~m}$ citrate-buffered saline, $\mathrm{pH}$ 6.0. Sections were then blocked for $1 \mathrm{~h}$ in $10 \%$ goat serum and incubated with the primary chicken antibody, anti-QR2 (1:200) overnight $(14-18 \mathrm{~h})$ at $4^{\circ} \mathrm{C}$. QR2 staining was revealed as described above.

Hippocampal cell cultures and experimental treatments. Hippocampal cell cultures were prepared from embryonic day 19 fetuses obtained from Sprague Dawley rats. Mixed (glial/neuronal) hippocampal cell cultures were obtained as described in detail previously (Bastianetto et al., 2006). Cells were grown at day 0 (density of $\sim 4 \times 10^{4}$ viable cells per well in 96-well plates) in HEPES-buffered DMEM high glucose supplemented with fetal bovine serum $10 \%(\mathrm{v} / \mathrm{v})$. The initial medium was removed at day 2 and replaced with the same medium containing N2 supplement $1 \%$ $(\mathrm{v} / \mathrm{v})$. The experiments were performed using 6-d-old cultures.

Menadione- and growth medium deprivation-induced toxicity. On day 6 of plating, cells were exposed for $24 \mathrm{~h}$ to menadione $(8 \mu \mathrm{M})$ in a DMEM high glucose, in the presence or absence of either S26695 or S29434 (1-30 $\mu \mathrm{M})$. Alternatively, hippocampal cells were incubated in HBSS without $\mathrm{N} 2$ supplement for $30 \mathrm{~min}$. Mitochondrial activity and cell viability were determined $24 \mathrm{~h}$ later using methylthiazoletetrazolium (MTT) and calcein AM assays, respectively. The MTT colorimetric assay is based on the ability of the mitochondrial enzyme succinate dehydrogenase to metabolize MTT into formazan, a reaction that takes place only in functionally intact mitochondria. The formation of formazan was estimated spectrophotometrically at $570 \mathrm{~nm}$ using a microplate reader (Bio-Tek Instruments), as described previously (Bozyczko-Coyne et al., 1993). Cell survival was assessed $24 \mathrm{~h}$ later using the calcein cell survival assay. Cal- 
cein is a nonfluorescent cell-permeant dye that is transported through the cellular membrane into live cells. It is then converted to a green fluorescent calcein after hydrolysis by intracellular endogenous esterases (Bozyczko-Coyne et al., 1993). Briefly, culture media were removed and the hippocampal cells were incubated with phenol red-free DMEM containing calcein $\mathrm{AM}(5 \mu \mathrm{M})$ for $30 \mathrm{~min}$ at $37^{\circ} \mathrm{C}$. After a one-step wash, calcein uptake into living cells of each well was automatically quantified (excitation at $485 \mathrm{~nm}$; emission wavelength at $530 \mathrm{~nm}$ ) using a fluorescence plate reader (Bio-Tek Instruments).

SYTO 16 and ethidium bromide staining of apoptotic nuclei. Apoptosis was estimated using the fluorescent nuclear dyes SYTO 16 and ethidium bromide (EB). These staining methods have been validated as an indicator of apoptotic cell death (Hueber et al., 1994; Sparrow and Tippett, 2005). After a $5 \mathrm{~h}$ treatment with menadione $(8 \mu \mathrm{M})$, culture medium was removed and the hippocampal cells were exposed to phenol red-free DMEM containing either SYTO $16(2 \mu \mathrm{M})$ or EB $(5 \mu \mathrm{g} / \mathrm{ml})$ for $30 \mathrm{~min}$ at $37^{\circ} \mathrm{C}$. A microplate fluorescence reader was used to automatically quantify the number of apoptotic neurons by assessing the enhanced SYTO 16 (excitation at $485 \mathrm{~nm}$; emission wavelength at $530 \mathrm{~nm}$ ) or EB (excitation at $510 \mathrm{~nm}$; emission wavelength at $590 \mathrm{~nm}$ ) staining.

Surgery and pump implantation for intracerebroventricular infusion. Rats (3-4 months old) were implanted with an Alzet model 2001 osmotic pump, which delivers $1.0 \mu \mathrm{l} / \mathrm{h}$ of the QR2 inhibitor S26695 for 1 week. Animals were anesthetized and placed in a stereotaxic frame, and the scalp was reflected under sterile surgical conditions. The intraventricular catheters were placed in relation to bregma at $1.4 \mathrm{~mm}$ lateral and $0.8 \mathrm{~mm}$ posterior on the right and then lowered $4.5 \mathrm{~mm}$ under the top of the skull. Catheters were attached to extension tubes and linked to the Alzet pumps, which were installed in subcutaneous pockets on the lateral back of the rats.

Morris water maze task. Spatial learning of rodents (3- to 4-month-old rats and mice) was determined using the referenced learning version of the MWM task, a hippocampus-dependent behavioral task (Morris, 1984). Rodents were required to find, in a 1.4-m-diameter pool, a submerged platform ( $14 \mathrm{~cm}$ in diameter) located $2 \mathrm{~cm}$ below the surface of water $\left(24^{\circ} \mathrm{C}\right)$, rendered opaque by the addition of skim milk powder. Animals were pseudorandomly started from a different position at each trial and used distal visuospatial cues to find the hidden escape platform that remained in the center of the same quadrant throughout all the training days (Morris, 1984). Animals were given three trials of $90 \mathrm{~s} / \mathrm{d}$ with a 20 min intertrial interval over 5 consecutive days. Animals were guided to the platform if not located within $90 \mathrm{~s}$, and all rodents remained there for $10 \mathrm{~s}$ before removal. After the acquisition phase on day 5 , rats were given one probe trial of $60 \mathrm{~s}$ in which the platform was removed from the pool to evaluate the number of times the animal crossed the previous location of the platform, time spent in the target quadrant, and swimming speed. This trial was followed by one cued trial of $60 \mathrm{~s}$ in which the platform was visible to assess visual deficits and motivation to escape from water. After each trial, animals were immediately placed under heat lamps to dry and prevent hypothermia. The experimenter was blind to treatments and surgery performed on any animals. To control for possible effects resulting from circadian cycles, all trials were performed at approximately the same time of the day, between 11 and $13 \mathrm{~h}$. Data derived from the MWM task were recorded on computer using a video tracking system (HVS).

Object recognition test in mice. The procedure described by Mumby et al. (2002) was followed to test novel object recognition learning in C57BL/6 mice. Briefly, an open-field chamber (length $\times$ width $\times$ height, $45 \times 45 \times 45 \mathrm{~cm})$ made of dark Plexiglas was placed in a quiet room. First, mice of each genotype ( $n=8$ per genotype) were individually placed in the arena for $20 \mathrm{~min}$ each day for $3 \mathrm{~d}$ with two identical objects (toys with various shapes) to acclimatize them with the test condition. On the test day, mice (3-4 months old) were placed in the arena with two new identical objects and allowed to explore the objects for $5 \mathrm{~min}$ (familiarization phase). The mice were then removed and placed back into their respective home cage for $5 \mathrm{~min}$ (retention time), and the objects were replaced with two new objects; one of the new objects was identical in shape to the objects used during the familiarization phase and the other was of a novel shape. Mice were then reintroduced to the arena after the retention time period and allowed to explore the objects for $5 \mathrm{~min}$ (testing phase). Behavioral activity during the familiarization and testing phases were videotaped and analyzed by observer blind to the genotype. A mouse was considered to be involved in object exploration when its head was oriented directly toward the object and within $\sim 2-3 \mathrm{~cm}$ from it. The time was also included if the animal had at least one forepaw on the object or sniffing or licking the object. Posturing and mounting are not included in the measures of investigation. Animals were placed back to home cage for $24 \mathrm{~h}$ and on day 5 were reintroduced to the same novelty paradigm and allowed to explore objects for $5 \mathrm{~min}$ while being videotaped. Mice have a natural tendency to explore novel objects in their surroundings compared with objects already familiar. The exploration ratio was evaluated by the amount of time spent on the novel object compared with the total amount of time spent on both objects.

Rotarod behavior in mice. Motor learning was determined using a standard mouse rotarod (IITC 755 ROTA ROD; IITC Life Science), which provides an accelerating rotational speed from $4 \mathrm{rpm}$ at the start of the test to a maximum speed of 6,12 , and $24 \mathrm{rpm}$ on day 1 and from 4 to $25 \mathrm{rpm}$ on day 2 , and three trainings per day were performed. Animals were tested at 4 months. The latency to fall off the rotarod was determined automatically by a timer that measures to the nearest second. A cutoff latency of $120 \mathrm{~s}$ (day 1) and $300 \mathrm{~s}$ (day 2) was used for all rotarod assessments.

Prepulse inhibition behavior in mice. Prepulse inhibition (PPI) was assessed using startle chambers (SRLAB; San Diego Instruments) containing a clear Plexiglas cylinder, which houses the animal (3-4 months old) during the testing session. Background white noise of $70 \mathrm{~dB}$ was delivered throughout the testing session to mask extraneous noise. Each PPI session consisted of 12 startles, six prepulse and six no-stimulus (null) trials. Each session began with a 5 min acclimatization of background noise, followed by trials arranged in a pseudorandom order to 40 $\mathrm{ms} / 120 \mathrm{~dB}$ pulse. In the prepulse trials, the startle pulse was preceded (100 ms) by a $20 \mathrm{~ms}$ prepulse of varying intensity $(3,5,7,10,15$, and 20 $\mathrm{dB}$ above background). The degree of PPI was calculated as a percentage of each prepulse intensity: $\% \mathrm{PPI}=100 \times[1-($ mean prepulse trial mean null)/(mean startle - mean null)].

Elevated plus maze in mice. The elevated plus maze was constructed of wood, painted gray, consisted of four arms $(30 \times 5 \mathrm{~cm})$ shaped in the form of a cross, and was elevated $50 \mathrm{~cm}$ from the floor. Two opposite arms were enclosed by side and end walls ( $12 \mathrm{~cm}$ high), and the other two arms were open. The connecting (open) center area measured $5 \times 5 \mathrm{~cm}$. Each animal was placed into the center area of the plus maze facing an open arm. The animals (3-4 months old) were then permitted to explore the maze freely for a $5 \mathrm{~min}$ period while being videotaped. The total time spent in open arms, connecting center and closed arms, was evaluated for each group of mice.

Forced swim test in mice. This test was performed according to a published adaptation of the original Porsolt test for rats to mice (PetitDemouliere et al., 2005). Briefly, mice (3-4 months old) were placed in a $15-\mathrm{cm}$-diameter cylinder filled with water $\left(24 \pm 1^{\circ} \mathrm{C}\right)$. For a period of 5 min, a human observer positioned $1 \mathrm{~m}$ away recorded the time with a stopwatch that the mouse was actively swimming as opposed to passively floating. The criterion for active swimming behaviors was the use of both hindpaws and forepaws as well as an elongated body shape. A curled-up body shape and intermittent movements with only the hindpaws is characterized as passive floating.

Electrophysiological recording in hippocampal slices. Hippocampal slices were prepared as described previously (Wong et al., 2007). Briefly, under deep anesthesia, brains were rapidly removed, and coronal brain slices (350 $\mu \mathrm{m}$ thickness) containing the hippocampus were cut in hyperosmotic, ice-cold and carbogenated (bubbled by $95 \% \mathrm{O}_{2} / 5 \% \mathrm{CO}_{2}$ to maintain the $\mathrm{pH}$ at 7.4) slice cutting solution (in mм: 252 sucrose, $2.5 \mathrm{KCl}, 4$ $\mathrm{MgCl}_{2}, 0.1 \mathrm{CaCl}_{2}, 1.25 \mathrm{KH}_{2} \mathrm{PO}_{4}, 26 \mathrm{NaHCO}_{3}$, and 10 glucose) using a vibratome. Freshly cut slices were placed in an incubating chamber with carbogenated artificial CSF (ACSF) [in mM: $125 \mathrm{NaCl}, 2.5 \mathrm{KCl}, 1 \mathrm{MgCl}_{2}$, $2 \mathrm{CaCl}_{2}, 1.25 \mathrm{NaH}_{2} \mathrm{PO}_{4}, 26 \mathrm{NaHCO}_{3}$, and 25 glucose $\left.(\sim 310 \mathrm{mOsm} / \mathrm{l})\right]$. Slices were recovered at $32^{\circ} \mathrm{C}$ for $1 \mathrm{~h}$ and subsequently maintained at room temperature. Carbogenated ACSF, containing bicuculline methobromide $(5 \mu \mathrm{M})$ to block $\mathrm{GABA}_{\mathrm{A}}$ receptor-mediated inhibitory synaptic 

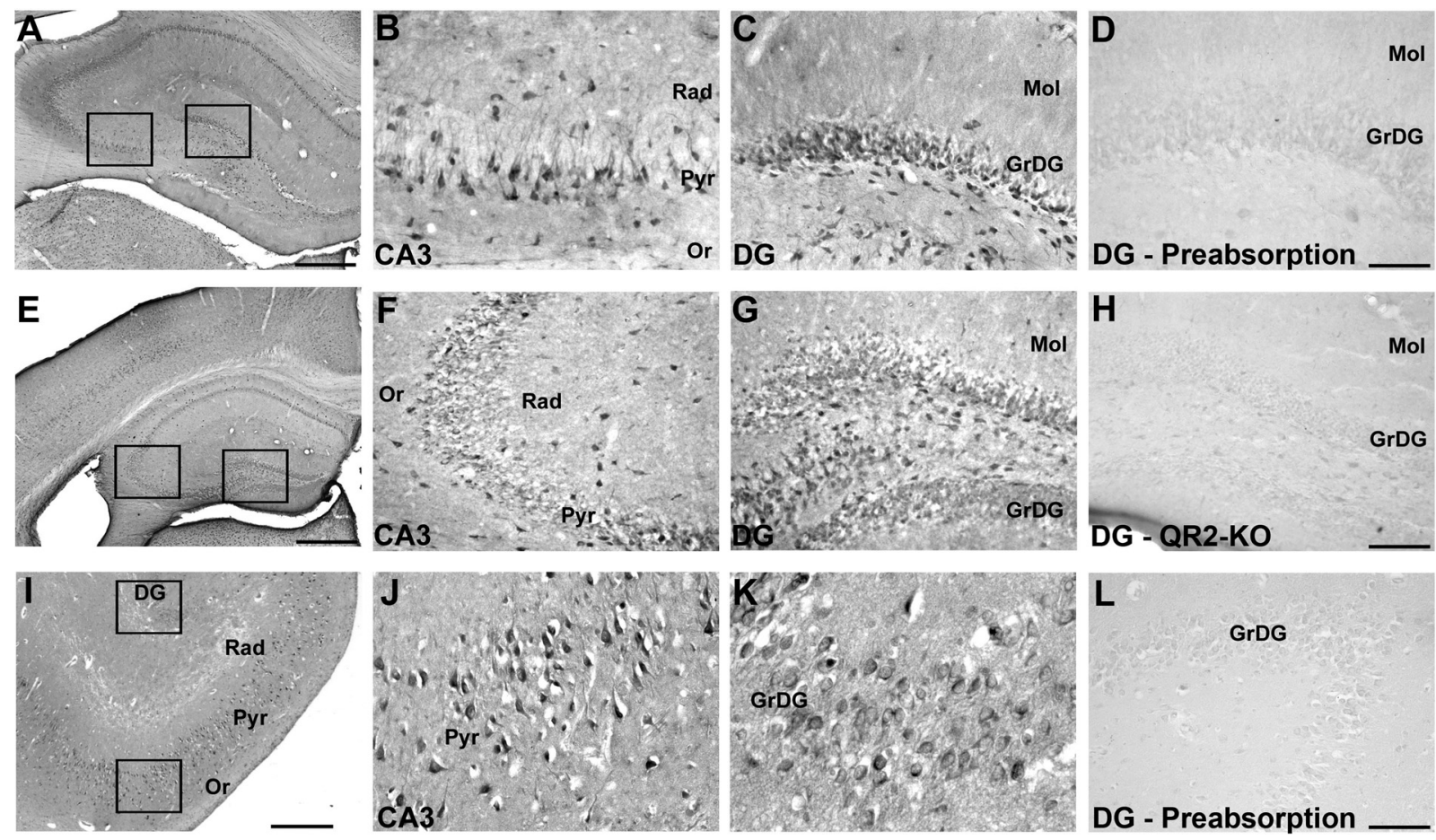

Figure 1. Distribution of $Q R 2$-like immunoreactivity $(I R)$ in the rat $(\boldsymbol{A}-\boldsymbol{D})$, mouse $(\boldsymbol{E}-\boldsymbol{H})$, and human $(\boldsymbol{I}-\boldsymbol{L})$ hippocampal formation. At low magnification, intense $Q R 2$-like immunolabeling is observed in the Ammon's horn fields (CA1-CA3) and dentate gyrus of the hippocampus $(\boldsymbol{A}, \boldsymbol{E}, \boldsymbol{I})$. At higher magnification, the majority of principal cells in the stratum pyramidale of $C A 1$ are immunopositively labeled, as well as sparse nonprincipal cells in stratum oriens and stratum radiatum $(\boldsymbol{B}, \boldsymbol{F}, \boldsymbol{J})$. QR2-like positive cells are observed in the stratum granulosum of the dentate gyrus, as are scattered neuron-like cells in the hilus $(\boldsymbol{C}, \boldsymbol{G}, \boldsymbol{K})$. Note the absence of immunostaining in the stratum granulosum in QR2 knock-out (KO) mouse dentate gyrus $(\boldsymbol{H})$ and after incubation of the QR2 antibody with the blocking peptide $(200 \mu \mathrm{g} / \mathrm{ml})$ in rat and human tissues $(\boldsymbol{D}, \boldsymbol{L})$. CA1-CA3, Fields CA1-CA3 of Ammon's horn; 0r, stratum oriens; Rad, stratum radiatum; Pyr, stratum pyramidale; DG, dentate gyrus; GrDG, stratum granulosum of the dentate gyrus; Mol, stratum moleculare of the dentate gyrus. Scale bars: $A, E, 500 \mu \mathrm{m} ; \boldsymbol{B}-\boldsymbol{D}, \boldsymbol{F}-\boldsymbol{H}, \boldsymbol{J}-\mathbf{L}, 100 \mu \mathrm{m} ; \boldsymbol{I}, 1 \mathrm{~mm}$.

currents, was used to perfuse slices in all recordings. Postsynaptic responses, which were evoked by stimulating the Schaffer collateral-commissural pathway via constant current pulses $(0.08 \mathrm{~ms})$ delivered through a tungsten bipolar electrode (FHC), were recorded from the hippocampal CA1 region, amplified by a Multiclamp 700B (Molecular Devices), and stored in a personal computer for offline analysis using Clampfit (Molecular Devices). All recordings were performed at room temperature. Field EPSP (fEPSP) was evoked at $0.05 \mathrm{~Hz}$ and detected by an ACSF-filled glass electrode that was placed in the stratum radiatum of the hippocampal CA1 region. Long-term plasticity of fEPSP such as long-term potentiation (LTP) and long-term depression (LTD) were induced by high-frequency $(100 \mathrm{~Hz}, 100$ pulses) and low-frequency (1 Hz, 900 pulses) tetani, respectively. Recording and analysis of electrophysiological data were performed blindly without knowing the mice phenotype.

Statistical analysis. Statistical analysis was conducted with Prism software (GraphPad Software). Differences and correlations were considered statistically significant when $p<0.05$.

\section{Results}

Overexpression of QR2 gene products in models of learning deficits

Previous work in our laboratory investigated gene expression profiles in the dorsal hippocampus of AI versus AU rats. Each animal was examined using individual Affymetrix high-density microarrays containing 28,757 genes. The gene for QR2 was among the few genes that were clearly upregulated in the hippocampus of AI versus AU rats (Brouillette and Quirion, 2008). An unpublished result also demonstrated the overexpression of the QR2 mRNA (1.57-fold over baseline) in the dorsal hippocampus in the scopolamine-induced amnesia rat model. The increase in QR2 expression was further confirmed by RT-PCR
(Brouillette et al., 2007; Brouillette and Quirion, 2008). Hence, the upregulation of the QR2 gene occurs in a pharmacologically induced model of learning impairments as well as in a model associated with age.

\section{Immunohistochemical distribution of QR2 in the hippocampus}

We first investigated the distribution of QR2-like immunoreactivity in the brain by using a specific polyclonal anti-QR2 antibody. The hippocampal formation, well documented for its implication in long term-memory (Scoville and Milner, 1957) and spatial navigation (O'Keefe, 1976), was among the most heavily labeled regions of the rat (Fig. $1 A-D$ ), mouse (Fig. $1 E-$ $H$ ), and human (Fig. $1 I-L$ ) brain. The staining was concentrated over neurons in all three species and was almost exclusively somatodendritic. In Ammon's horn (CA1-CA3 subfields), immunolabeling was confined to large pyramidal cells, including their apical dendrites extending into the stratum radiatum (Fig. $1 B, F, J)$. As evident at higher magnification, labeled interneurons were also sparsely distributed throughout the strata oriens and radiatum (Fig. $1 B, F, J$ ). In the dentate gyrus, the labeling predominated over granule cells, with a few moderately immunopositive cells in the hilus (Fig. $1 C, G, K$ ). QR2 knock-out (C57BL/6 $Q R 2^{-/-}$) mice were generated and used to test the specificity of our antibody. These animals showed normal neuroanatomy and cell positioning but without any QR2-like immunostaining (Fig. $1 H)$. Accordingly, rat and human brain sections incubated with antiserum preabsorbed with the immunogenic peptide were completely devoid of immunolabeling (Fig. $1 D, L$ ). 


\section{Immunohistochemical distribution of QR2 in the cortex}

Various cortical areas and laminae are involved in working memory and complex cognitive behaviors (Miller and Cohen, 2001). In all neocortical areas, densely packed pyramidal and nonpyramidal neurons were clearly enriched with QR2like immunoreactivity distributed across layers II-VI (Fig. 2A,B). At high magnification, neurons labeled in layer $\mathrm{V}$ of the rat frontal cortex were found to correspond to pyramidal cells displaying strong immunolabeling of both the cell body and apical dendrite (Fig. 2 E). Within the neuronal perikarya, QR2-like immunoreactivity was evenly distributed in the cytoplasm, with no apparent nuclear staining (Fig. 2 F). This lack of nuclear labeling confirms and extends information as to the cytosolic localization and activity of QR2. In addition, moderate numbers of QR2-like positive neurons were observed in layers II-IV (Fig. 2C,D) as well as in layer VI (Fig. $2 G, H$ ) of the frontal cortex.

\section{QR2 inhibitors protect hippocampal cells against menadione-induced toxicity and serum deprivation}

The action of two novel QR2 inhibitors, S26695 and S29434, were evaluated in a model of toxicity induced by menadione $(8 \mu \mathrm{M})$, a quinone exerting its toxic action through QR2 (Long et al., 2002). Our results revealed that a 24 h exposure to menadione was neurotoxic to hippocampal cells ( $~ 58-62 \%$ decrease in MTT values vs control and $54-58 \%$ decrease in calcein fluorescence vs control) (Fig. $3 A, B$ ). The toxic action of menadione was reversed in a concentration-dependent manner by cotreatment with S26695 (EC $\mathrm{EC}_{50}$ of $\left.32 \mu \mathrm{M}\right)$ and S29434 $\left(\mathrm{EC}_{50}\right.$ of $5 \mu \mathrm{M}$ ) (Fig. 3A). Moreover, S26695 and S29434 significantly increased the survival of hippocampal cells exposed to menadione, with an apparent $\mathrm{EC}_{50}$ of 23 and $34 \mu \mathrm{M}$, respectively (Fig. $3 B$ ). In another well-established model of toxicity induced by growth medium deprivation, the MTT colorimetric assay revealed that cells exposed to HBSS without N2 supplement for 30 min resulted in a $27 \%$ inhibition of MTT reduction compared with those exposed to a high-glucose DMEM (Fig. 3C). Inhibition of MTT reduction was concentration dependently reversed in the presence of S29434 $\left(\mathrm{EC}_{50}\right.$ of $\left.2.5 \mu \mathrm{M}\right)$ and to a lesser extent to S26695 (EC $\mathrm{E}_{50}$ of $\left.12 \mu \mathrm{M}\right)$. Thus, two inhibitors of QR2 enzymatic activity are able to protect hippocampal cells against neurotoxicity.

We further investigated the underlying mechanisms whereby QR2 affects learning and memory. Because menadione is a naphthoquinone that leads to the production of reactive oxygen species inside the cells and causes dramatic changes in mitochondrial metabolism (Gerasimenko et al., 2002; Criddle et al., 2006; Kawamura et al., 2006), we examined whether the selective inhibitors of QR2 were able to protect against menadione-induced apoptosis. The number of menadione-treated cells stained with either SYTO 16 or ethidium bromide increased by 68 and 77\%, indicating that menadione exerts an apoptotic effect on hippocampal neuronal cells (Fig. $4 A, B$ ). Both assays further revealed that the number of apoptotic cells was significantly reduced after coincubation with the QR2 inhibitors. At a concentration of 20 $\mu \mathrm{M}$, found to be neuroprotective in the MTT assay, both S26695 $(133 \pm 10$ vs $168 \pm 11$ and $142 \pm 7$ vs $177 \pm 12$ in SYTO 16 and ethidium bromide assays, respectively) and S29434 (127 \pm 7 vs $168 \pm 11$ and $149 \pm 8$ vs $177 \pm 12$ in SYTO 16 and ethidium bromide assays, respectively) reversed the proapoptotic action of menadione.

\section{QR2 inhibition can reverse cognitive deficits}

Scopolamine-treated rats $(2 \mathrm{mg} / \mathrm{kg})$ are commonly used as a psychopharmacological model of learning impairments. To determine whether the loss of QR2 function resulted in cognitive improvements in this model, the specific inhibitor S26695 (8 $\mathrm{mg} / \mathrm{kg}$ ) was chronically injected intracerebroventricularly using osmotic minipumps. Four-month-old rats were then tested in the Morris water maze task. The treatment with S26695 significantly reversed scopolamine-induced amnesia (Fig. 5A) $\left({ }^{*} p<0.05\right.$, twoway ANOVA, $n=12$ ). In the probe trial, scopolamine-treated animals showed no preference for the quadrant that previously contained the platform (Fig. $5 B$ ) but displayed fewer platform crossings (Fig. $5 C$ ). In the cued component of the test, we observed similar escape latency to the visible platform, indicating the absence of visual, sensorimotor, or motivational deficits in any of the groups tested here. Scopolamine-induced impairment was also not attributed to slower swimming speed because these rats swam somewhat faster than control animals (Fig. 5D).

To further investigate the possible role of QR2 in learning behaviors, C57BL/6 QR2-deficient mice $\left(\mathrm{QR} 2^{-/-}\right)$were generated and tested in a battery of cognitive tasks, using first the mouse version of the Morris water maze. $Q R 2^{-/-}$mice demonstrated improved learning abilities by having a shorter latency to locate the hidden platform from days 2 to 4 in the spatial component of the test (Fig. 6A) $\left({ }^{*} p<0.05\right.$, two-way ANOVA, $n=$ 19). These mice also exhibited similar learning performance as their WT littermates, as shown by the amount of time they spent 

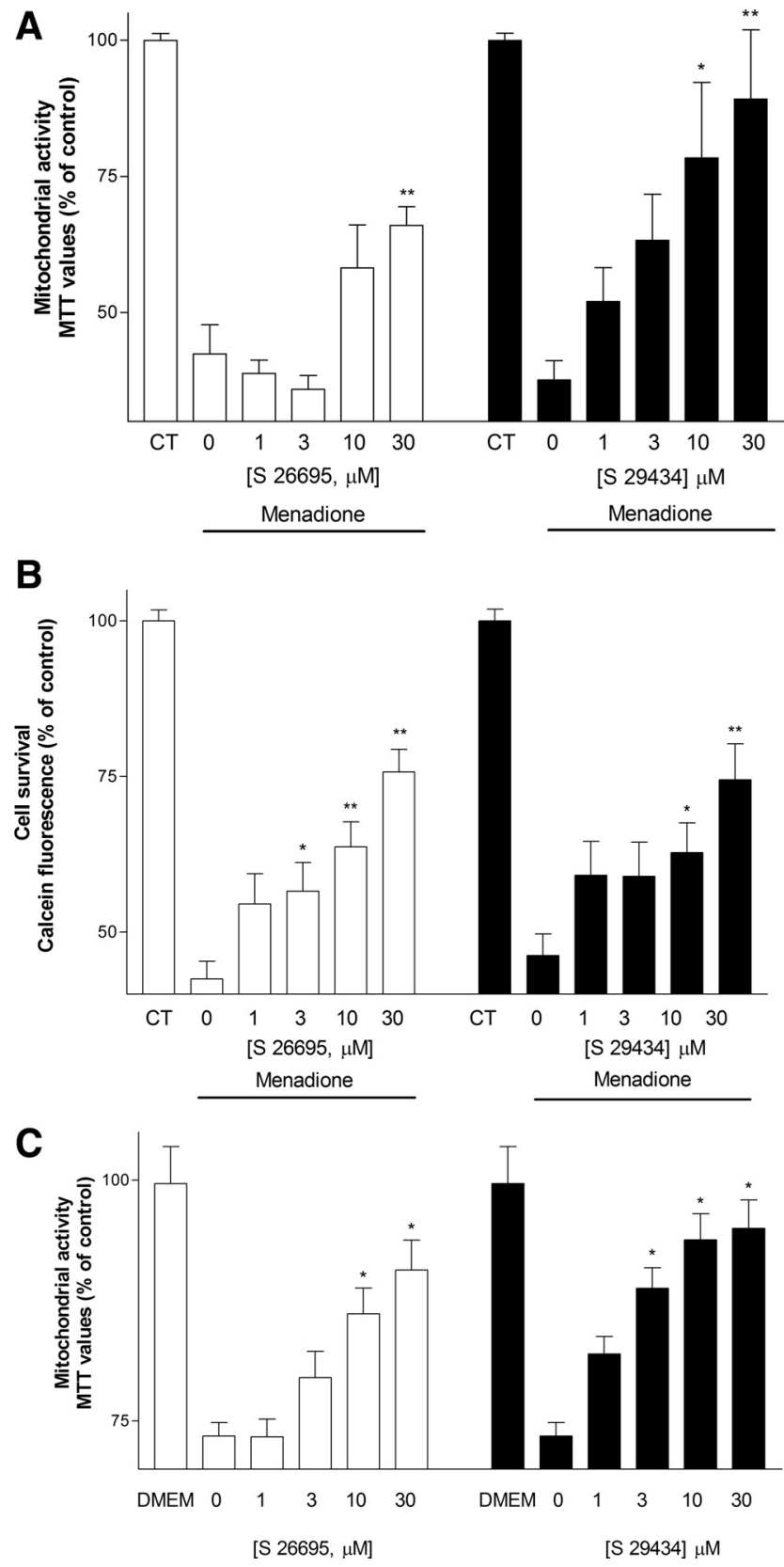

Figure 3. Effect of treatment with $\mathrm{S} 26695(1-30 \mu \mathrm{M})$ and $\mathrm{S} 29434(1-30 \mu \mathrm{M})$ on toxicity induced by menadione $(8 \mu \mathrm{M})$, as estimated by the MTT $(\boldsymbol{A})$ and calcein $(\boldsymbol{B})$ assays and on toxicity induced by growth medium deprivation, as estimated by the MTT assay (C). Data represent mean \pm SEM of three separate experiments. ${ }^{*} p<0.05$, ${ }^{* *} p<0.01$ compared with groups treated with menadione or HBSS alone.

in the target quadrant during the probe test (Fig. 6B) and the amount of time they crossed the platform location (Fig. 6C). These data are in accordance with the observed acquisition phase on day 5 (Fig. $6 A$ ).

\section{QR2 inactivation facilitates learning behaviors}

Mice were then tested in the novel object recognition task to evaluate their working memory. This cognitive task was used to determine the ability of QR2-deficient mice in discriminating novel versus familiar objects (Fig. 7A). Two-way ANOVA of the exploration ratio for the novel object showed a significant effect of genotype for the new object. Indeed, WT and $Q R 2^{-/-}$displayed similar interest in the original novelty exposure on the
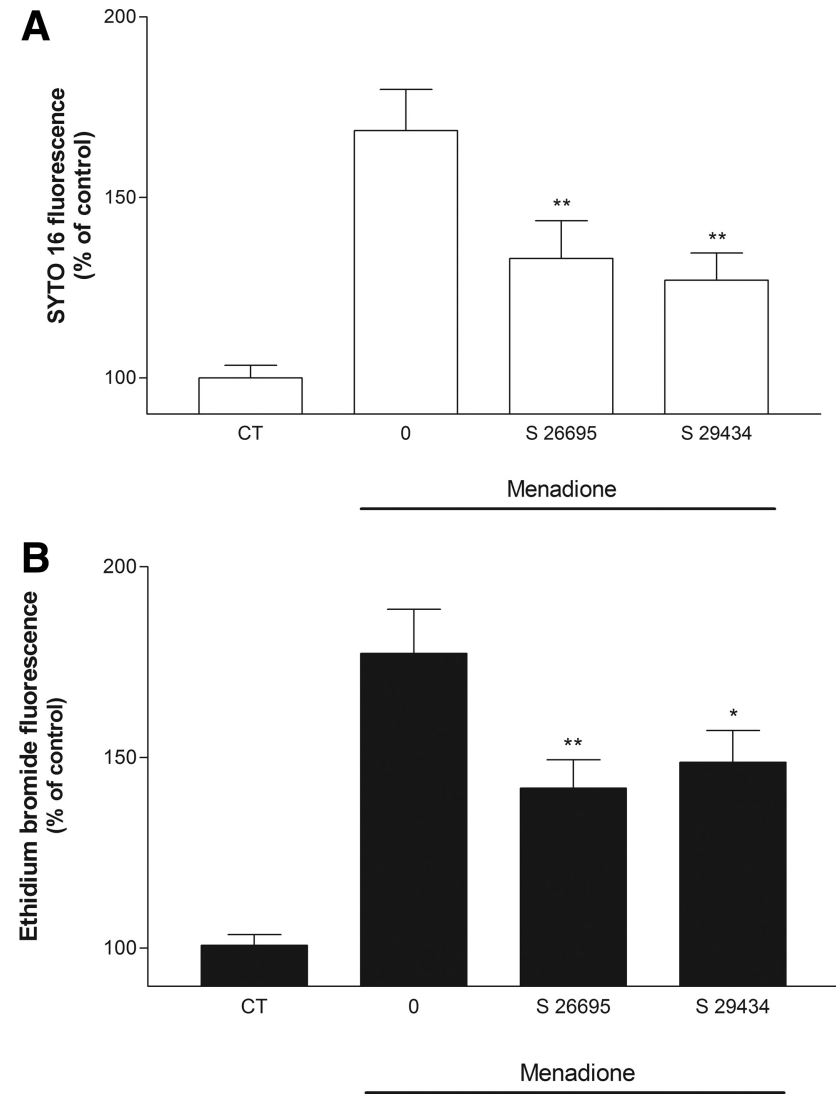

Figure 4. Effect of $S 26695(20 \mu \mathrm{M})$ and $\mathrm{S} 29434(20 \mu \mathrm{M})$ against apoptotic events induced by menadione $(8 \mu \mathrm{M})$, as revealed by the fluorescent dyes SYT0 $16(\boldsymbol{A})$ and ethidium bromide $(\boldsymbol{B})$. Values represent mean \pm SEM of three separate experiments. ${ }^{*} p<0.05,{ }^{* *} p<0.01$ compared with groups treated with menadione alone. CT, Control.

habituation day (day 4), but when presented with the same object in similar context, $Q R 2^{-/-}$mice performed significantly better, revealing a long-term memory improvement over their WT counterparts (day 5$)(n=8)$. Similar results were obtained in another strain (NMRI) of mice (data not shown).

To investigate motor learning, the rotarod test was used for $2 \mathrm{~d}$ as a means to evaluate the capacity of an animal to retain the task (Fig. $7 B$ ). On the first day, no difference in the latency to fall off the rotarod equipment was seen between groups. However, on day 2, we observed a significant increase in the latency to fall in $\mathrm{QR} 2^{-/-}$mice, suggesting improved motor learning in these animals $(n=12)$.

\section{Performance of $Q R 2^{-/-}$mice in other behaviors}

To establish whether the effects observed in learning processes were specific to cognitive impairment, $Q R 2^{-/-}$mice were tested for their abilities to perform in a variety of unrelated behavioral assays. Decrease in baseline magnitude of the startle response in the PPI test is linked to abnormalities of sensorimotor gating in both animals and human. These deficits are often associated with schizophrenia-like behaviors (Swerdlow et al., 1991). On a gradient of prepulse stimuli ranging from 73 to $90 \mathrm{~dB}$, we therefore tested responses of $Q R 2^{-/-}$versus WT littermates. No significant differences were observed (Fig. 8A).

The elevated plus maze is commonly used to assess anxietylike behaviors in rodents (Pellow et al., 1985). We thus evaluated the amount of time spent in each zone of the maze, namely the closed arms, the center connecting closed to open arms, and the 
open arms. No difference was detected between $Q R 2^{-/-}$and WT mice (Fig. $8 B$ ).

The forced swim test is often used as an acute model of depression responsive to currently available therapies (West, 1990; Thiebot et al., 1992). The time an animal spends still is translated as the lack of will to get out of the water or a depression-like behavior. Again, no significant difference was observed between $Q R 2^{-/-}$and WT mice in this behavior task (Fig. 8C).

\section{Electrophysiology experiments}

Because LTP and LTD are well-established models of neural plasticity associated with learning behaviors, we investigated next their possible alterations in $Q R 2^{-/-}$mice. We first examined a form of commonly studied LTP in the hippocampal CA1 region that is induced by high-frequency stimulation (HFS) $(100 \mathrm{~Hz}, 100$ pulses $)$ in control and $Q R 2^{-/-}$mice (8-10 weeks old) (Fig. 9A). Comparing the fEPSP slope at 55-60 min after HFS revealed no effect of $Q R 2^{-1-}$ on the percentage potentiation of fEPSP slope. Next, we examined the potential impact of $Q R 2^{-/-}$on LTD induced by low-frequency stimulation (LFS) (1 $\mathrm{Hz}, 900$ pulses) (Fig. 9B). Along with previous findings that LTD is difficult to be induced in the adult hippocampus (Kemp et al., 2000), we failed to induce LFS-LTD in adult control and $Q R 2^{-/-}$mice $(8-10$ weeks old). To ascertain the effect of $Q R 2^{-/-}$on LTD, we examined LFS-LTD in young (3 weeks old) control and $\mathrm{QR} 2^{-/-}$mice. Although we were able to induce LTD in these younger mice, we again observed no effect of $Q R 2^{-/-}$on this form of plasticity. Together, lacking QR2 has no effect on two commonly studied forms of bidirectional hippocampal synaptic plasticity.

\section{Discussion}

The main findings of our study include the following: (1) the increased expression of the QR2 gene in the hippocampal formation of scopolamine-treated as well as aged memory-impaired rat models; (2) the broad expression of QR2 in the brain with particular enrichments in neurons of the hippocampus and cortex in rodents and human; (3) the ability of selective QR2 inhibitors to act as neuroprotective agents in two models of neurotoxicity in vitro and to reverse the proapoptotic action of QR2; (4) the capacity of these inhibitors to facilitate learning behaviors in rodents; (5) the facilitated cognitive abilities of $Q R 2^{-1-}$ mice in various learning tasks; and (6) the apparent selective nature of enhanced learning capacities as be-
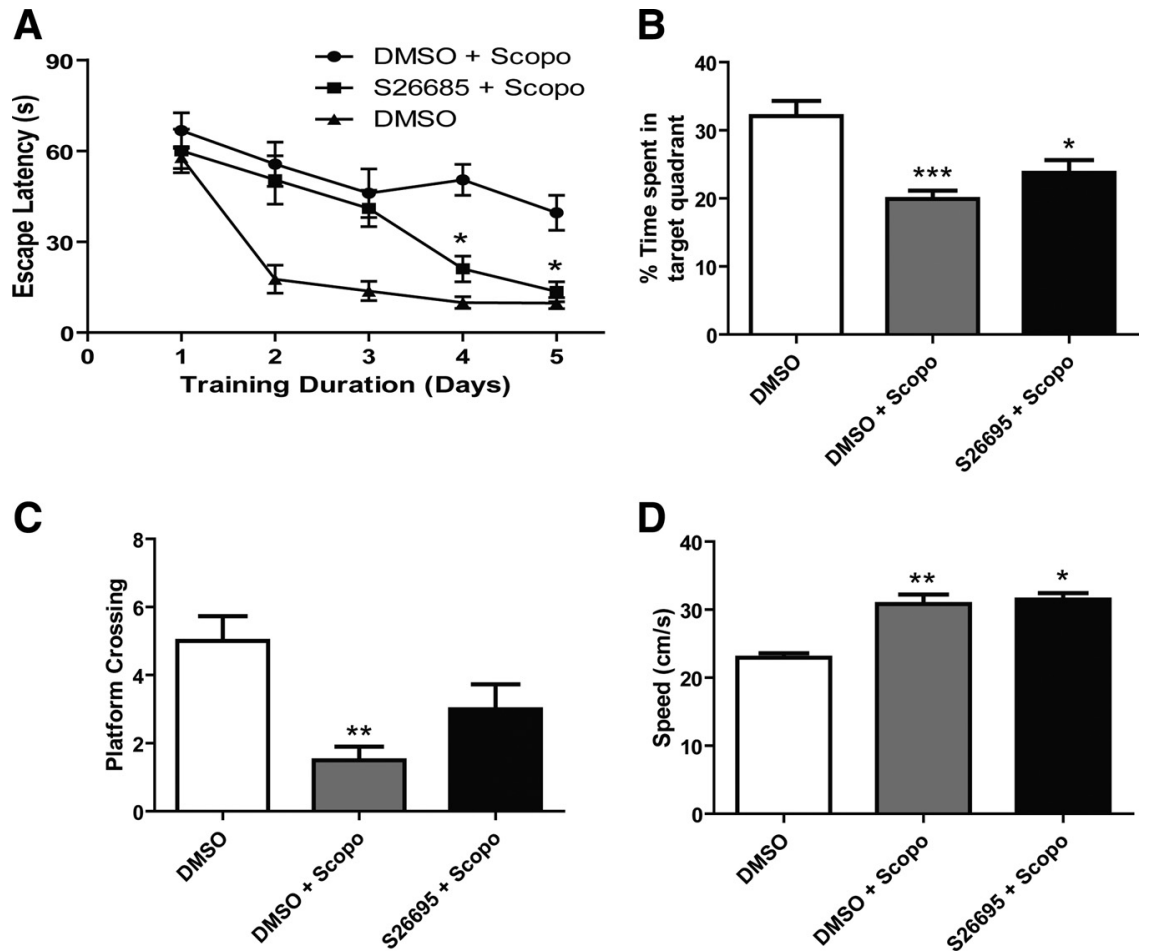

Figure 5. Learning performance in scopolamine-treated rats in the Morris water maze task. $A$, Spatial learning impairments of scopolamine-treated rats are reversed by the QR2 inhibitor $\$ 26695$ injected intracerebroventricularly $(8 \mathrm{mg} / \mathrm{kg})$ when tested in the MWM. Escape latencies are shorter for $\$ 26695$-treated rats $(S 26695+S c o p 0 ; n=8)$ than scopolamine-treated animals (DMSO + Scopo; $n=12$ ), reaching the level of untreated sham rats on days 4 and 5 (DMSO; $n=6 ;{ }^{*} p<0.05$, two-way ANOVA). $\boldsymbol{B}$, Percentage time spent in the quadrant that previously contained the platform during the probe trial. Significant difference between both $\$ 26695$-treated and scopolamine-treated control (DMSO + Scopo) compared with untreated sham animals (DMSO) $\left({ }^{*} p<0.05 ;{ }^{* * *} p<0.001\right.$; one-way ANOVA). C, Number of crossings to the previous location of the platform during probe test. Significant difference between scopolamine-treated (DMSO + Scopo) and untreated control (DMSO) $\left({ }^{* *} p<0.01\right.$, one-way ANOVA). $\boldsymbol{D}$, Treatment with scopolamine produced a significant increase in swimming speed compared with nontreated young rats $\left({ }^{*} p<0.01 ;{ }^{* *} p<0.001\right.$, one-way ANOVA). All results are means \pm SEM.
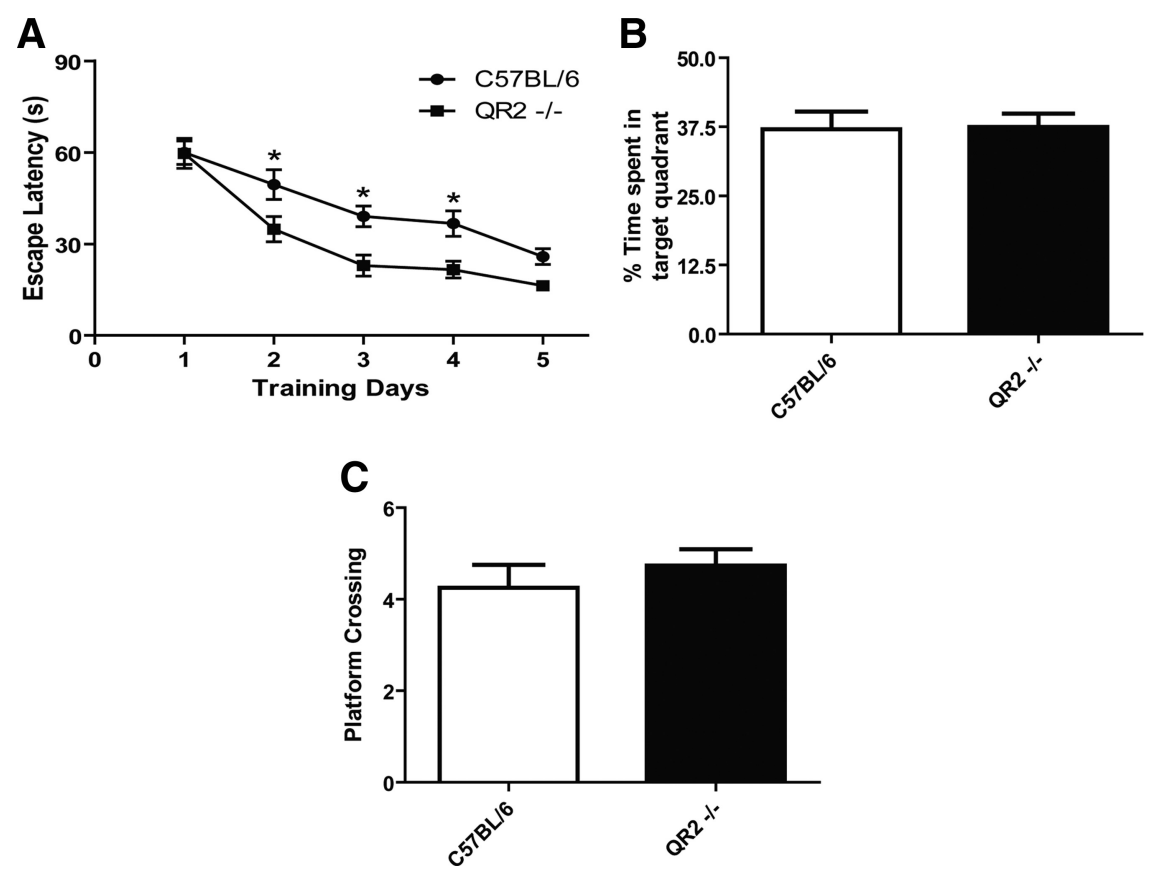

Figure 6. Learning performance in quinone reductase 2 knock-out mice $\left(Q R 2^{-/-}\right)$in the Morris water maze task. $\boldsymbol{A}$, Escape latencies to find the hidden-platform are shorter for $Q R 2^{-/-}$mice $(n=19)$ than WT $(n=20)$ on days $2-4\left({ }^{*} p<0.05\right.$, two-way ANOVA). No differences were detected between WT and $Q R 2^{-/-}$for the percentage time spent in target quadrant $(\boldsymbol{B})$ or in the number of platform crossings (C). 
A Object Recognition

B

Rotarod
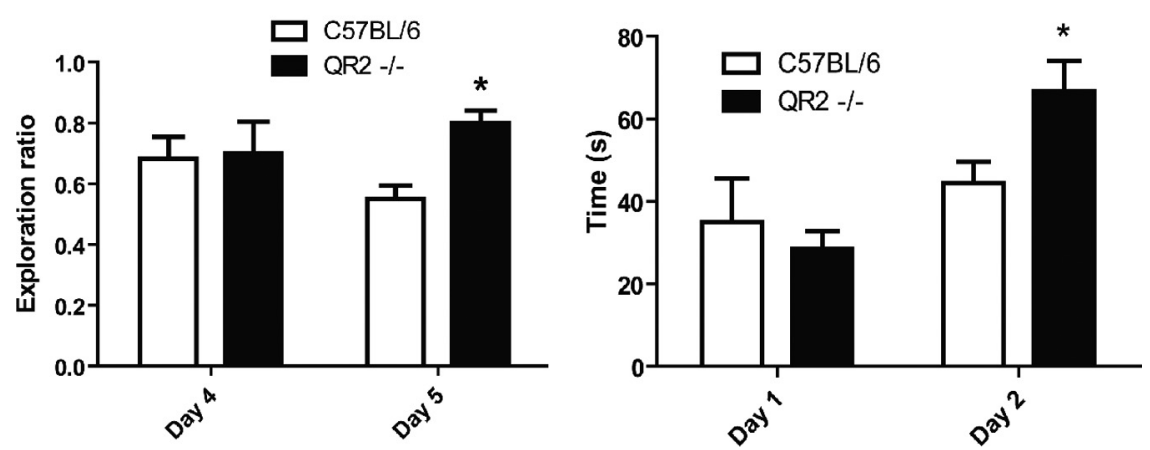

Figure 7. Learning performances in $\mathrm{C} 57 \mathrm{BL} / 6$ and quinone reductase 2 knock-out $\left(\mathrm{QR2^{-/- }}\right)$ mice determined using both novel object recognition and rotarod tests. $A$, Novel object recognition in wild-type and $Q R 2^{-/-}$. Exploration ratios reveal that $Q R 2^{-/-}$ mice display preference for the novel object compared with controls ( ${ }^{*} p<0.05$, two-way ANOVA with Bonferroni's post hoc tests. $n=8) . \boldsymbol{B}$, Learning behaviors on day 2 in the rotarod test. On day 1 , no difference is detected between groups, whereas on day 2 , $Q R 2^{-1-}$ show improvement in apparent learning compared with WT ( ${ }^{*} p<0.05$, paired $t$ test; $n=12$ ).
A

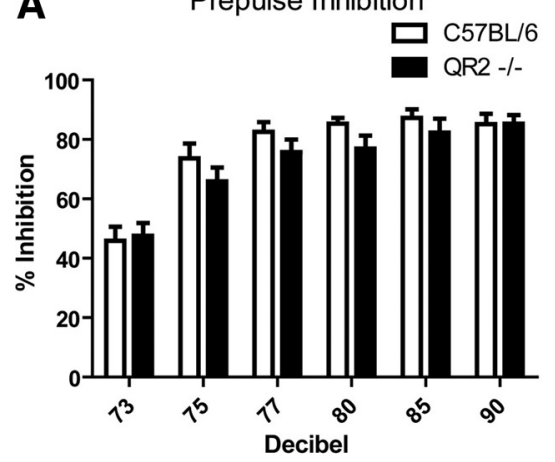

B

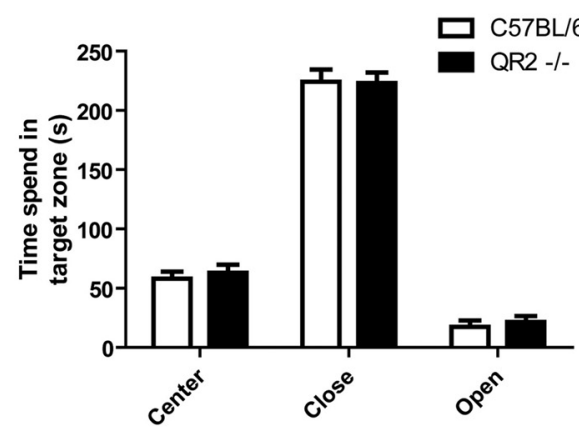

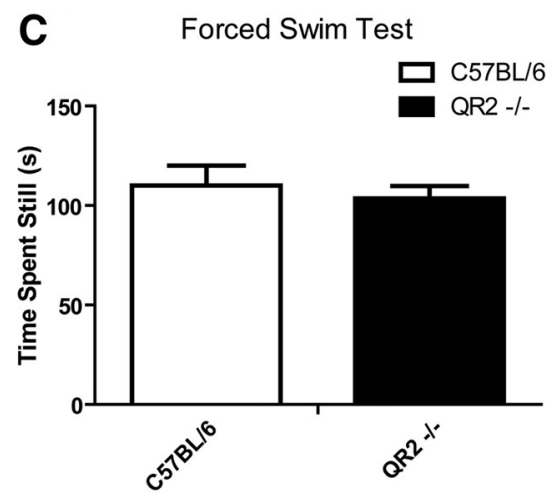

Figure 8. Comparative performance of $Q R 2^{-1-}$ and wild-type mice in schizophrenia-, anxiety-, and depression-related behaviors. No difference was seen between $Q R 2^{-1-}$ and wild-type littermates in the magnitude of startle response using PPI $(n=$ 12), a behavior associated with psychosis $(\boldsymbol{A})$. Similarly, no difference was observed in the elevated plus maze test, an anxiety-like behavior $(\boldsymbol{B})$, or in the forced swim test, a depression-associated behavior (C).

haviors related to anxiety, depression, and psychosis are not altered in $Q R 2^{-/-}$mice. Together, these data strongly suggest that QR2 should be considered as a novel and potent modulator of cognitive processes in the mammalian brain. Selective QR2 inhibitors should possibly be considered as cognition enhancers in the treatment of brain disorders associated with learning deficits, including various forms of dementias.

Our cDNA microarray study revealed that few genes were apparently upregulated or downregulated in both the AI versus AU rat and scopolamine-induced amnesia models. This suggests the likely functional relevance of these alterations. Indeed, be- sides data shown here on the upregulated gene QR2, we have recently reported on the role of the downregulated gene transthyretin (TTR) in learning behaviors via the modulation of the availability of retinoids (Brouillette and Quirion, 2008). Moreover, TTR appears to act as a potent scavenger of amyloid proteins, its gene deletion accelerating the development of an Alzheimer's disease-like phenotype in mouse models (Choi et al., 2007; Brouillette and Quirion, 2008; Buxbaum et al., 2008). Hence, a comparative analysis of genes that are similarly altered in at least two models of learning behaviors has proven to be a successful strategy to uncover novel genes and gene products possibly involved in learning and cognition.

QR2-like immunoreactivity was shown here to be similarly distributed in both rodent and human brains. QR2 staining is particularly abundant in brain regions involved in cognition, such as the hippocampal formation and various cortical areas. Interestingly, the cellular localization of QR2 is apparently restricted to the cytoplasm of neurons with no or very low staining observed in glia. These results suggest that QR2 is likely to preferentially regulate neuronal functions.

Recently, the successful development of highly selective inhibitors of QR2 was reported (Mailliet et al., 2005). These molecules were originally targeted for the treatment of peripheral disorders, including a better understanding of the role of QR2 in various physiological or pathological conditions, because it was shown that QR2 expression and activity would lead to an enhanced production of ROS (Gong et al., 2008). The used inhibitors were cocrystallized with QR2 with a complete set of data of the characteristics of these compounds as well as the currently used substrates and co-substrates (Ferry et al., 2010). In the present study, we demonstrated that these molecules could also prove to be useful as neuroprotective agents and cognitive enhancers. Indeed, the selective QR2 inhibitors S26695 and S29434 were shown to protect neurons against death induced by the deprivation of nutrients or by menadione, an enzyme substrate known to be very damaging to cells after being reduced and activated by the catalytic activity of QR2 (Long et al., 2002). The toxic effects of menadione most likely involve the increased production of ROS inside the cells and the alteration of mitochondrial metabolism, thus affecting the properties of cell plasma membranes (Morgan et al., 1998; Gerasimenko et al., 2002; Criddle et al., 2006; Kawamura et al., 2006). We also found that the QR2 inhibitors were able to reduce menadione-induced apoptosis, probably through the inhibition of the intrinsic (i.e., mitochondrial) pathway (Degterev 

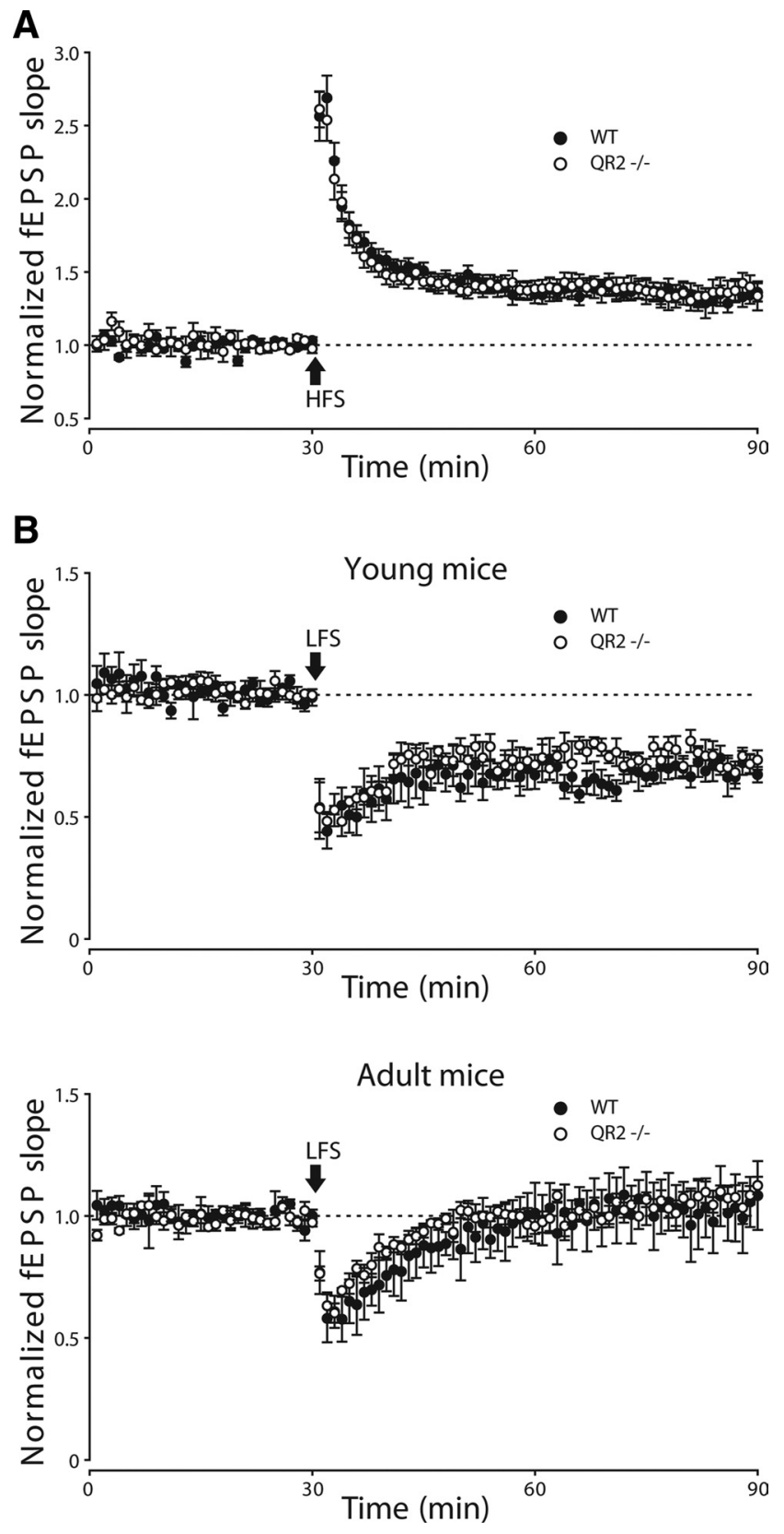

Figure 9. Bidirectional hippocampal synaptic plasticity in quinone reductase 2 knock-out mice $\left(Q R 2^{-1-}\right) \cdot A$, Long-term potentiation was induced by HFS ( $100 \mathrm{~Hz}$, 100 pulses). No difference between WT $(n=11)$ and $Q R 2^{-1-}(n=9)$ mice was found. $\boldsymbol{B}$, Long-term depression (induced by LFS: $1 \mathrm{~Hz}, 900$ pulses) was examined in both young (top) and adult (bottom) WT $(n=5)$ and $Q R 2^{-1-}(n=5)$ mice. We observed no changes in LTD between these two types of mouse in both age groups.

and Yuan, 2008; Gorman, 2008; Zhivotovsky and Orrenius, 2010).

Interestingly, the two QR2 inhibitors were shown to be highly effective in vivo in both rat and mouse models of learning. These inhibitors significantly reversed scopolamine-induced amnesia in the rats and facilitated object recognition in the mouse after single or repeated administration of the molecule. The production of a QR2 knock-out mouse model provided additional key evidence on the selective role of QR2 in learning paradigms. Most importantly, adult $Q R 2^{-/-}$mice demonstrated improved cognitive performances in various models of learning behaviors. Indeed, $Q R 2^{-/-}$displayed increased capacities in models of spatial
(MWM and passive avoidance), motor (rotarod), and attentional (object recognition) behaviors. These are rather unique observations because it is very rare that knock-out animals of any type will demonstrate improved cognitive performances even in only one learning task (more typical to observe decreased abilities). Few examples have been reported in the literature included in HDAC2 histone deacetylase (Guan et al., 2009) and Ncx2 calcium exchanger protein mice (Jeon et al., 2003). The finding that facilitated learning capacities is rather selective with other types of behavior related to anxiety, depression, and psychosis not being affected in $Q R 2^{-/-}$mice makes our observations even more exciting, highlighting the possibly unique role of this enzyme in cognitive behaviors.

Quinone reductase 2 knock-out provides protection against menadione toxicity in vivo (Long et al., 2002). This indicates that QR2 is involved in the activation of this particular quinone. QR2 does not recognize nicotinamide adenine dinucleotide (NADH) as a co-substrate (Zhao et al., 1997) in contrast to QR1, the major quinone detoxification enzyme. Instead, QR2 recognizes a breakdown product of NADH, N-ribosyl-dihydronicotinamide $(\mathrm{NRH})$. This has been enforced by in vivo experiments in which the coinjection of $\mathrm{NRH}$ with menadione in $Q R 2^{-/-}$mice led greater toxicity of the quinone (Long et al., 2002). It has been shown in neurodegenerative diseases that QR2 is overexpressed, suggesting that enhanced activity of QR2 could lead to neuronal cell death (Harada et al., 2001; Wang et al., 2008). This is likely attributable to two independent factors, namely the induction of the protein and the availability of NRH. QR2 activity leads to hydroquinone and semi-quinone, the latter being a deleterious species for the cell (Chomarat et al., 2007). Its activity is also accompanied by increased production of ROS deleterious for the cell (Gong et al., 2008). Accordingly, under stress and challenging conditions, QR2 is overexpressed and catalytically active, potentially leading to altered mechanisms of defense such as catalase and glutathione (Dröge and Schipper, 2007).

Although both spatial and object recognition learning were improved after knocking down QR2, this genetic manipulation did not enhance two commonly studied forms of hippocampal plasticity, which are HFS-LTP and LFS-LTD. One possible explanation is that the gain in learning performance could be attributable to factors that are unrelated to CA1 hippocampal synaptic plasticity. For instance, rodents displayed spatial learning during MWM acquisition (decrease in escape latency with training) even when synaptic plasticity was abolished by NMDA receptor blockade or knockdown (Morris et al., 1986; Silva et al., 1992). These findings suggest that nonspatial strategies could be used by rodents to resolve a spatial task. Similarly, evidences have been reported demonstrating that alteration of learning could occur without evident changes in LTP or LTD (Bannerman et al., 1997). For example, although intracerebroventricular infusion of an NMDA receptor-associated glycine site antagonist 7-chlorokynurenate impaired MWM performances, this drug has no effect on hippocampal LTP. Additional studies will need to examine whether $Q R 2^{-/-}$enhance the flexibility of rodents to use multiple behavioral approaches to solve learning tasks that are used in this study. Finally, our electrophysiological findings do not rule out potential effects of QR2 deficiency on untested forms of synaptic plasticity such as late-LTP and short-term synaptic plasticity or on plasticity at CA3 and dentate gyrus synapses (Kandel, 2001; Zucker and Regehr, 2002).

The inhibition of the enzyme by specific blockers has been suggested as a possible novel approach in the treatment of various diseases associated with learning deficits. Indeed, QR2 inhibitors 
and $Q R 2^{-/-}$mice demonstrated the unique and selective role of this enzyme in the regulation of various types of learning behaviors in rodents.

\section{References}

Bannerman DM, Butcher SP, Good MA, Morris RG (1997) Intracerebroventricular infusion of the NMDA receptor-associated glycine site antagonist 7-chlorokynurenate impairs water maze performance but fails to block hippocampal long-term potentiation in vivo. Neurobiol Learn Mem 68:252-270.

Bastianetto S, Yao ZX, Papadopoulos V, Quirion R (2006) Neuroprotective effects of green and black teas and their catechin gallate esters against beta-amyloid-induced toxicity. Eur J Neurosci 23:55-64.

Bozyczko-Coyne D, McKenna BW, Connors TJ, Neff NT (1993) A rapid fluorometric assay to measure neuronal survival in vitro. J Neurosci Methods 50:205-216.

Brouillette J, Quirion R (2008) Transthyretin: a key gene involved in the maintenance of memory capacities during aging. Neurobiol Aging 29:1721-1732.

Brouillette J, Young D, During MJ, Quirion R (2007) Hippocampal gene expression profiling reveals the possible involvement of Homerl and GABA(B) receptors in scopolamine-induced amnesia. J Neurochem 102:1978-1989.

Buxbaum JN, Ye Z, Reixach N, Friske L, Levy C, Das P, Golde T, Masliah E, Roberts AR, Bartfai T (2008) Transthyretin protects Alzheimer's mice from the behavioral and biochemical effects of Abeta toxicity. Proc Natl Acad Sci U S A 105:2681-2686.

Choi SH, Leight SN, Lee VM, Li T, Wong PC, Johnson JA, Saraiva MJ, Sisodia SS (2007) Accelerated A $\beta$ deposition in APPswe/PS1 $\Delta \mathrm{E} 9$ mice with hemizygous deletions of TTR (transthyretin). J Neurosci 27:7006-7010.

Chomarat P, Cogé F, Guénin SP, Mailliet F, Vella F, Mallet C, Giraudet S, Nagel N, Leonce S, Ferry G, Delagrange P, Boutin JA (2007) Cellular knock-down of quinone reductase 2: a laborious road to successful inhibition by RNA interference. Biochimie 89:1264-1275.

Criddle DN, Gillies S, Baumgartner-Wilson HK, Jaffar M, Chinje EC, Passmore S, Chvanov M, Barrow S, Gerasimenko OV, Tepikin AV, Sutton R, Petersen OH (2006) Menadione-induced reactive oxygen species generation via redox cycling promotes apoptosis of murine pancreatic acinar cells. J Biol Chem 281:40485-40492.

Degterev A, Yuan J (2008) Expansion and evolution of cell death programmes. Nat Rev Mol Cell Biol 9:378-390.

Dröge W, Schipper HM (2007) Oxidative stress and aberrant signaling in aging and cognitive decline. Aging Cell 6:361-370.

Ferry G, Hecht S, Berger S, Moulharat N, Coge F, Guillaumet G, Leclerc V, Yous S, Delagrange P, Boutin JA (2010) Old and new inhibitors of quinone reductase 2. Chem Biol Interact 186:103-109.

Frick KM, Baxter MG, Markowska AL, Olton DS, Price DL (1995) Agerelated spatial reference and working memory deficits assessed in the water maze. Neurobiol Aging 16:149-160.

Gage FH, Dunnett SB, Bjorklund A (1989) Age-related impairments in spatial memory are independent of those in sensorimotor skills. Neurobiol Aging 10:347-352.

Gerasimenko JV, Gerasimenko OV, Palejwala A, Tepikin AV, Petersen OH, Watson AJ (2002) Menadione-induced apoptosis: roles of cytosolic $\mathrm{Ca}^{2+}$ elevations and the mitochondrial permeability transition pore. J Cell Sci 115:485-497.

Gong X, Gutala R, Jaiswal AK (2008) Quinone oxidoreductases and vitamin K metabolism. Vitam Horm 78:85-101.

Gorman AM (2008) Neuronal cell death in neurodegenerative diseases: recurring themes around protein handling. J Cell Mol Med 12:2263-2280.

Guan JS, Haggarty SJ, Giacometti E, Dannenberg JH, Joseph N, Gao J, Nieland TJ, Zhou Y, Wang X, Mazitschek R, Bradner JE, DePinho RA, Jaenisch R, Tsai LH (2009) HDAC2 negatively regulates memory formation and synaptic plasticity. Nature 459:55-60.

Harada S, Fujii C, Hayashi A, Ohkoshi N (2001) An association between idiopathic Parkinson's disease and polymorphisms of phase II detoxification enzymes: glutathione S-transferase M1 and quinone oxidoreductase 1 and 2. Biochem Biophys Res Commun 288:887-892.

Harada S, Tachikawa H, Kawanishi Y (2003) A possible association between an insertion/deletion polymorphism of the NQO2 gene and schizophrenia. Psychiatr Genet 13:205-209.
Hueber AO, Pierres M, He HT (1994) Quantitating apoptosis by a nonradioactive DNA dot blot assay. Anal Biochem 221:431-433.

Igaz LM, Vianna MR, Medina JH, Izquierdo I (2002) Two time periods of hippocampal mRNA synthesis are required for memory consolidation of fear-motivated learning. J Neurosci 22:6781-6789.

Irizarry RA, Bolstad BM, Collin F, Cope LM, Hobbs B, Speed TP (2003) Summaries of Affymetrix GeneChip probe level data. Nucleic Acids Res 31:e15.

Jeon D, Yang YM, Jeong MJ, Philipson KD, Rhim H, Shin HS (2003) Enhanced learning and memory in mice lacking $\mathrm{Na}^{+} / \mathrm{Ca}^{2+}$ exchanger 2 . Neuron 38:965-976.

Kandel ER (2001) The molecular biology of memory storage: a dialogue between genes and synapses. Science 294:1030-1038.

Kawamura F, Hirashima N, Furuno T, Nakanishi M (2006) Effects of 2-methyl-1,4-naphtoquinone (menadione) on cellular signaling in RBL2H3 cells. Biol Pharm Bull 29:605-607.

Kemp N, McQueen J, Faulkes S, Bashir ZI (2000) Different forms of LTD in the CA1 region of the hippocampus: role of age and stimulus protocol. Eur J Neurosci 12:360-366.

Long DJ 2nd, Iskander K, Gaikwad A, Arin M, Roop DR, Knox R, Barrios R, Jaiswal AK (2002) Disruption of dihydronicotinamide riboside:quinone oxidoreductase 2 (NQO2) leads to myeloid hyperplasia of bone marrow and decreased sensitivity to menadione toxicity. J Biol Chem 277:46131-46139.

Mailliet F, Ferry G, Vella F, Berger S, Cogé F, Chomarat P, Mallet C, Guénin SP, Guillaumet G, Viaud-Massuard MC, Yous S, Delagrange P, Boutin JA (2005) Characterization of the melatoninergic MT3 binding site on the NRH:quinone oxidoreductase 2 enzyme. Biochem Pharmacol 71:74-88.

Mattson MP, Magnus T (2006) Ageing and neuronal vulnerability. Nat Rev Neurosci 7:278-294.

Miller EK, Cohen JD (2001) An integrative theory of prefrontal cortex function. Annu Rev Neurosci 24:167-202.

Morgan WA, Kaler B, Bach PH (1998) The role of reactive oxygen species in adriamycin and menadione-induced glomerular toxicity. Toxicol Lett 94:209-215.

Morris R (1984) Developments of a water-maze procedure for studying spatial learning in the rat. J Neurosci Methods 11:47-60.

Morris RG, Anderson E, Lynch GS, Baudry M (1986) Selective impairment of learning and blockade of long-term potentiation by an N-methyl-Daspartate receptor antagonist, AP5. Nature 319:774-776.

Mumby DG, Glenn MJ, Nesbitt C, Kyriazis DA (2002) Dissociation in retrograde memory for object discriminations and object recognition in rats with perirhinal cortex damage. Behav Brain Res 132:215-226.

Ohgake S, Hashimoto K, Shimizu E, Koizumi H, Okamura N, Koike K, Matsuzawa D, Sekine Y, Inada T, Ozaki N, Iwata N, Harano M, Komiyama T, Yamada M, Sora I, Ujike H, Shirayama Y, Iyo M (2005) Functional polymorphism of the NQO2 gene is associated with methamphetamine psychosis. Addict Biol 10:145-148.

O'Keefe J (1976) Place units in the hippocampus of the freely moving rat. Exp Neurol 51:78-109.

Okubo T, Harada S, Higuchi S, Matsushita S (2003) Association analyses between polymorphisms of the phase II detoxification enzymes (GSTM1, NQO1, NQO2) and alcohol withdrawal symptoms. Alcohol Clin Exp Res 27:68S-71S.

Pellow S, Chopin P, File SE, Briley M (1985) Validation of open:closed arm entries in an elevated plus-maze as a measure of anxiety in the rat. J Neurosci Methods 14:149-167.

Petit-Demouliere B, Chenu F, Bourin M (2005) Forced swimming test in mice: a review of antidepressant activity. Psychopharmacology (Berl) 177:245-255.

Rowe WB, Spreekmeester E, Meaney MJ, Quirion R, Rochford J (1998) Reactivity to novelty in cognitively-impaired and cognitively-unimpaired aged rats and young rats. Neuroscience 83:669-680.

Scoville WB, Milner B (1957) Loss of recent memory after bilateral hippocampal lesions. J Neurol Neurosurg Psychiatry 20:11-21.

Serrano F, Klann E (2004) Reactive oxygen species and synaptic plasticity in the aging hippocampus. Ageing Res Rev 3:431-443.

Silva AJ, Paylor R, Wehner JM, Tonegawa S (1992) Impaired spatial learning in alpha-calcium-calmodulin kinase II mutant mice. Science 257:206-211.

Sparrow RL, Tippett E (2005) Discrimination of live and early apoptotic 
mononuclear cells by the fluorescent SYTO 16 vital dye. J Immunol Methods 305:173-187.

Stemmelin J, Lazarus C, Cassel S, Kelche C, Cassel JC (2000) Immunohistochemical and neurochemical correlates of learning deficits in aged rats. Neuroscience 96:275-289.

Swerdlow NR, Keith VA, Braff DL, Geyer MA (1991) Effects of spiperone, raclopride, SCH 23390 and clozapine on apomorphine inhibition of sensorimotor gating of the startle response in the rat. J Pharmacol Exp Ther 256:530-536.

Thiebot MH, Martin P, Puech AJ (1992) Animal behavioural studies in the evaluation of antidepressant drugs. Br J Psychiatry Suppl 44-50.

Vella F, Ferry G, Delagrange P, Boutin JA (2005) NRH:quinone reductase 2: an enzyme of surprises and mysteries. Biochem Pharmacol 71:1-12.

Wang W, Jaiswal AK (2004) Sp3 repression of polymorphic human NRH: quinone oxidoreductase 2 gene promoter. Free Radic Biol Med 37:12311243.

Wang W, Le WD, Pan T, Stringer JL, Jaiswal AK (2008) Association of NRH: quinone oxidoreductase 2 gene promoter polymorphism with higher gene expression and increased susceptibility to Parkinson's disease. J Gerontol A Biol Sci Med Sci 63:127-134.

West AP (1990) Neurobehavioral studies of forced swimming: the role of learning and memory in the forced swim test. Prog Neuropsychopharmacol Biol Psychiatry 14:863-877.

Wong TP, Howland JG, Robillard JM, Ge Y, Yu W, Titterness AK, Brebner K, Liu L, Weinberg J, Christie BR, Phillips AG, Wang YT (2007) Hippocampal long-term depression mediates acute stress-induced spatial memory retrieval impairment. Proc Natl Acad Sci U S A 104:1147111476.

Zhao Q, Yang XL, Holtzclaw WD, Talalay P (1997) Unexpected genetic and structural relationships of a long-forgotten flavoenzyme to $\mathrm{NAD}(\mathrm{P}) \mathrm{H}$ : quinone reductase (DT-diaphorase). Proc Natl Acad Sci U S A 94:16691674.

Zhivotovsky B, Orrenius S (2010) Cell death mechanisms: cross-talk and role in disease. Exp Cell Res 316:1374-1383.

Zucker RS, Regehr WG (2002) Short-term synaptic plasticity. Annu Rev Physiol 64:355-405. 